T.M. Budnyak ${ }^{1}$, V.A. Tertykh ${ }^{1}$, E.S. Yanovska ${ }^{2}$

\title{
CHITOSAN IMMOBILIZED ON SAPONITE SURFACE IN EXTRACTION OF V(V), Mo(VI) AND Cr(VI) OXOANIONS
}

\author{
${ }^{1}$ Chuiko Institute of Surface Chemistry of National Academy of Sciences of Ukraine \\ 17 General Naumov Str., Kyiv, 03164, Ukraine, E-mail: tetyanabudnyak@yahoo.com \\ ${ }^{2}$ Taras Shevchenko National University of Kyiv, Faculty of Chemistry \\ 64 Volodymyrska Str., Kyiv, 01033, Ukraine
}

Chitosan-saponite composite has been obtained by crosslinking of adsorbed on saponite surface biopolymer with glutaraldehyde. The structure of composite was studied by IR-spectroscopy, concentration of immobilized chitosan was estimated using thermogravimetric analysis. The adsorption of microquantities of $V(V), M o(V I)$, and $\operatorname{Cr}(V I)$ oxoanions by obtained composite, initial natural mineral and polymer has been studied from aqueous solutions. The sorption capacities and kinetics adsorption characteristics of the composite adsorbent were estimated.

Keywords: adsorption, chitosan, saponite, clay, vanadium, molybdenum, chromium

\section{INTRODUCTION}

Saponite (saponite clay) of Ukrainian Podillya refers to the class of bentonites, subclass of layered magnesium silicate montmorillonite where $\mathrm{Al}^{3+}$ are almost completely replaced by $\mathrm{Mg}^{2+}$ and $\mathrm{Si}^{4+}$ replaced by $\mathrm{Al}^{3+}$ in their structural framework. Besides of those elements, the structure of saponite includes more than 35 other biological active chemical elements in micro and ultramicro amounts: iron, fluorine, calcium, potassium, sodium, zinc, cobalt, copper, nickel, vanadium, molybdenum, etc. According to the fact that the natural mineral possesses ion-exchanging and adsorption properties, it is widely used in treatment technologies as mineral fertilizer, food additive in animal husbandry and cosmetics. In Ukraine saponite was certificated as lightly porous filler; as sorbent for milk, milk products and other liquid food products purification from heavy metals and radionuclides; as complex mineral additive for fodders [1-5].

Adsorbents of natural origin are widely used for water treatment in order to replace current costly methods of heavy metals elimination from solutions. To improve the adsorption properties of mineral adsorbents it is expedient to immobilize the appropriate substances with well-pronounced ion-exchanging and complexing properties onto their surfaces. Application for these purpose natural biopolymers, such as a nitrogen-containing polysaccharide chitosan, is of a great interest [6-8].
Properties of inorganic sorbents could be upgraded by valuable characteristics of organic polymer. In particular, chitosan has good biocompatibility, high adhesion to the surface, a wide range of $\mathrm{pH}$ stability, expressed chelating properties. Natural minerals are characterized by advanced surface stability in the acidic medium, acceptable kinetics, thermal stability, and resistance to microbial attack.

Recent studies in that field have been shown that composites of silica and chitosan [6-13] and biosorbents based on chitosan and different natural minerals [14-21] can be used for extraction and concentration of toxic metals from solutions. However, there is necessity in systematic investigations of adsorption properties of chitosanmineral composites, in particular to study an effect of nature and $\mathrm{pH}$ of solutions and to determine achievable values of adsorption capacity. The peculiarities of chitosan coating formation on the surface of saponite, as well as adsorption properties of the synthesized composite with respect to vanadium(V), molybdenum(VI), and chromium(VI) oxoanions have been studied in this work.

\section{EXPERIMENTAL SECTION}

Saponite of Ukrainian Podillya with general formula $\left(\mathrm{Ca}_{5}, \mathrm{Na}\right)_{3}(\mathrm{Mg}, \mathrm{Fe})_{3}(\mathrm{Si}, \mathrm{Al})_{4} \mathrm{O}_{10}(\mathrm{OH})_{2} \cdot 4 \mathrm{H}_{2} \mathrm{O}$ was impregnated by chitosan solution (Sigma Aldrich, N 417 963) with a molecular weight from 190,000 to $370,000 \mathrm{Da}$, degree of deacetylation not less than $75 \%$ and solubility $10 \mathrm{mg} / \mathrm{ml} .20 \mathrm{~g}$ of 
saponite and $285 \mathrm{ml}$ of $7 \mathrm{mg} / \mathrm{ml}$ chitosan solution in acetic acid ( $\mathrm{pH}$ 2.6) were put in flat-bottom flask and mixed by the magnetic stirrer MM-5 for $2 \mathrm{~h}$. The obtained substance was dried at $50{ }^{\circ} \mathrm{C}$. The structure of surface of saponite with adsorbed chitosan is schematically presented in Fig. 1.

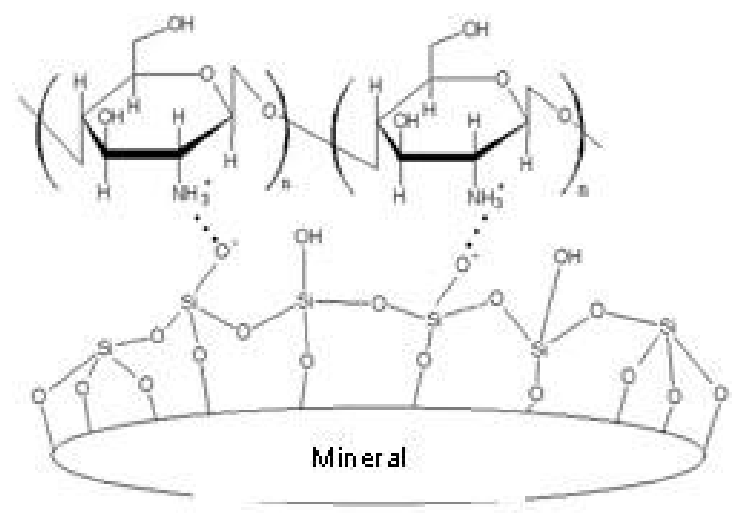

Fig. 1. The scheme of interaction between saponite surface and adsorbed chitosan

Crosslinking of adsorbed polymer with glutaraldehyde was performed in order to consolidate better the surface layer because it is important in case of application of the composite in the acidic solutions. For this purpose, $10 \mathrm{ml}$ of $0.025 \%$ glutaraldehyde solution was added to the saponite with the preadsorbed chitosan and stirred for $2 \mathrm{~h}$. According to the calculations, used amount of dialdehyde provides crosslinking about $5 \%$ of amino groups in the polymer layer. The obtained product was washed with repeated decantation and dried at $50{ }^{\circ} \mathrm{C}$ to constant weight. As a result, chitosan-saponite composite with weight ratio chitosan: silica $-1: 10$ was synthesized.

The investigations of adsorption properties of the obtained composite with respect to $\mathrm{V}(\mathrm{V})$, $\mathrm{Mo}(\mathrm{VI})$, and $\mathrm{Cr}(\mathrm{VI})$ oxoanions were carried out in the static mode with periodic hand-stirring. For that, sample of $0.1 \mathrm{~g}$ of synthesized adsorbent was contacted with $25 \mathrm{ml}$ of solutions with different concentrations of salts: $\mathrm{NH}_{4} \mathrm{VO}_{3}$, $\left(\mathrm{NH}_{4}\right)_{6} \mathrm{Mo}_{7} \mathrm{O}_{24} \cdot 4 \mathrm{H}_{2} \mathrm{O},\left(\mathrm{NH}_{4}\right)_{2} \mathrm{Cr}_{2} \mathrm{O}_{7}$ prepared under recommendations [22]. Photometric studies of equilibrium solutions were performed according to the methods described in [23, 24] using a SF-46 spectrophotometer (LOMO, Russia) with square cuvettes (optical path length $l=1 \mathrm{~cm}$ ).

IR spectra of samples of initial materials and reaction products were recorded using IR spectrophotometer with Fourier transformation (Thermo Nicolet Nexus FT-IR, USA). For this purpose the samples was grinded in an agate mortar and pressed with $\mathrm{KBr}$. The concentration of chitosan on the surface of saponite was determined by thermogravimetric method on a Q-1500 MOM (Hungary) derivatograph with the computer data registration in the temperature range $15-1000{ }^{\circ} \mathrm{C}$. Samples heating rate was 10 degrees/min. DTA, TG and DTG curves were recorded simultaneously.

The degree of adsorption $(R)$ was calculated using the formula:

$$
R=\left(m_{\mathrm{ads}} / m_{\mathrm{o}}\right) \cdot 100 \%=\left(m_{\mathrm{0}}-m\right) / m_{\mathrm{0}} \cdot 100 \%,
$$

where $m_{0}$ is the weight of the metal in the initial solution, $m_{\text {ads }}$ is the weight of adsorbed metal, $m$ is the weight of metal in solution after adsorption equilibrium, which was calculated as $m=C \cdot V$, where $C$ is the equilibrium concentration of metal and $V$ is the volume of equilibrium solution.

\section{RESULTS AND DISCUSSION}

In the FTIR spectrum of chitosan (Fig. 2) the band at $3429 \mathrm{~cm}^{-1}$ corresponds to the stretching vibrations $\mathrm{O}-\mathrm{H}$ of hydroxyl groups bound with carbon atoms. Intensive absorbance bands at $2800-3000 \mathrm{~cm}^{-1}$ due to the $\mathrm{C}-\mathrm{H}$ stretching vibrations. The bands $1580 \mathrm{~cm}^{-1}$ of the bending vibrations of $-\mathrm{NH}_{2}, 1420$ and $1380 \mathrm{~cm}^{-1}$ for $\mathrm{C}-\mathrm{H}$ binding vibrations, $1310 \mathrm{~cm}^{-1}$ for asymmetric $\mathrm{C}-\mathrm{O}-\mathrm{C}$ stretching vibrations, and $1080 \mathrm{~cm}^{-1}$ for $\mathrm{C}-\mathrm{O}$ stretching vibration of $\mathrm{CH}-\mathrm{OH}$ were observed.

The FTIR spectrum of the synthesized chitosan-saponite has shown a shift of the band of $-\mathrm{NH}_{2}$ bending vibrations in comparison with the spectrum of initial chitosan. An intensive absorbance at $1000 \mathrm{~cm}^{-1}$ represents the $\mathrm{Si}-\mathrm{O}$ stretching vibrations. The bands at 518 and $466 \mathrm{~cm}^{-1}$ correspond to $\mathrm{Al}-\mathrm{O}-\mathrm{Si}$ and $\mathrm{Si}-\mathrm{O}-\mathrm{Si}$ bending vibrations, respectively. FTIR spectrum of composite showed the absorption band at $1650 \mathrm{~cm}^{-1}$ which corresponds to stretching vibrations of azomethine bonds $\mathrm{C}=\mathrm{N}$ formed after treatment with glutaraldehyde $[25,26]$.

The thermogravimetric analysis (hereinafter TG) of saponite, chitosan and synthesized composite were conducted in order to determine the concentration of immobilized chitosan (Fig. 3). For TG-curve of chitosan (Fig. $3 a$ ) two decomposition temperature can be noticed. The initial weight loss of $11 \%$ from room temperature $\left(30{ }^{\circ} \mathrm{C}\right)$ up to $190{ }^{\circ} \mathrm{C}$ corresponds to the release of adsorbed water. The second recorded 
decomposition region $\left(190-1000{ }^{\circ} \mathrm{C}\right)$ completely applies to weight loss of chitosan. As for clay (рис. $3 \mathrm{~b}$ ), the first decomposition $\left(30-200{ }^{\circ} \mathrm{C}\right.$ ) corresponds to the weight loss of $11 \%$ due to removal of adsorbed water. The next weight loss $\left(200-1000{ }^{\circ} \mathrm{C}\right)$ involved major weight loss of the hydroxyl structure in clay, with $83 \%$ residue remained as metal oxides included into the composition of the mineral. The thermogravimetric curve of composite chitosan-saponite (Fig. $3 c$ ) is characterized by decomposition region from 30 to $200{ }^{\circ} \mathrm{C}$ which is similar to initial materials and corresponds to water desorption with following decomposition of organic part of composite at higher temperatures $\left(200-1000^{\circ} \mathrm{C}\right)$. Similar observations have been found in [25, 28-30].

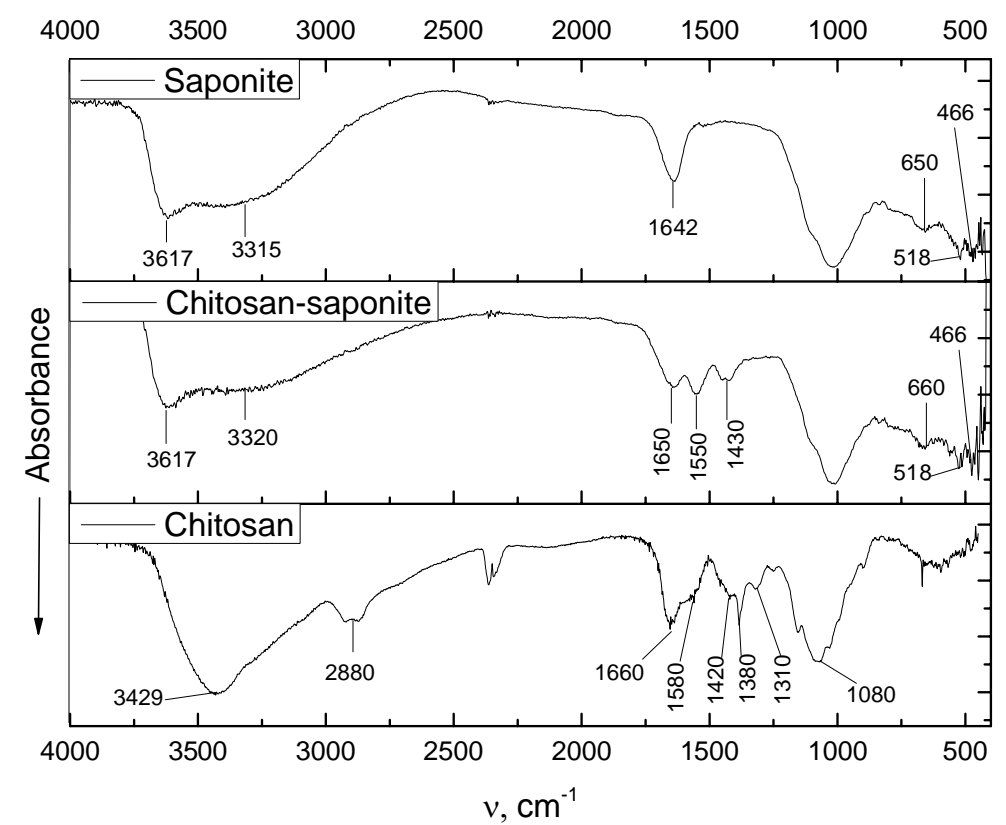

Fig. 2. FTIR spectra of saponite, chitosan and composite chitosan-saponite

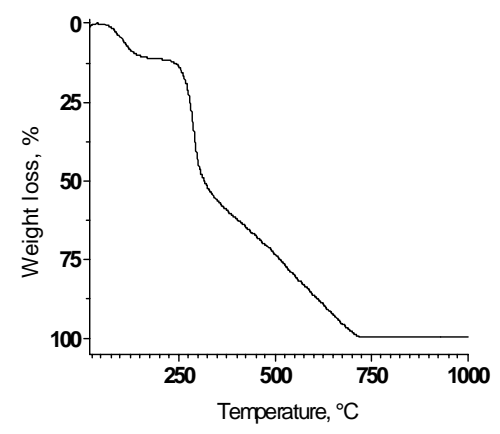

$a$

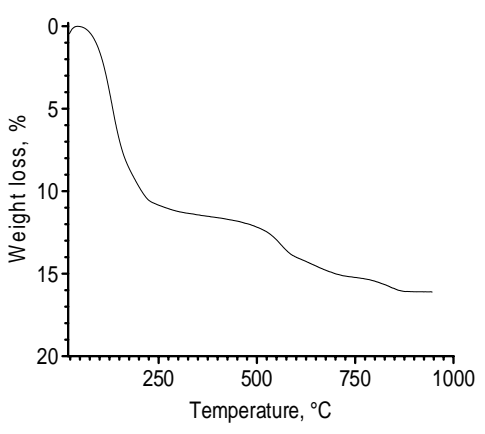

$b$

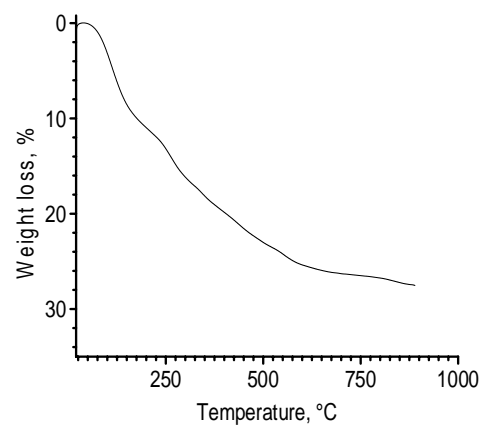

$c$

Fig. 3. TG-curves of chitosan (a), saponite (b) and composite chitosan-saponite $(c)$

The comparison of TG-curves of saponite, chitosan and composite chitosan-saponite shows that in the temperature range from 200 to $1000{ }^{\circ} \mathrm{C}$ weight losses of the composite silica-chitosan, which are most likely caused by destruction of the organic component of the composite, reach about $9.1 \%$. Comparison this value with the weight of chitosan, which has been taken for the composite synthesis, shows almost complete polymer anchorage on the saponite surface. According to that, one gram of the carrier was coated by approximately $91 \mathrm{mg}$ of chitosan.

First of all, at investigation of sorption properties of the synthesized composite optimum values of medium acidity for the highest removal of the studied ions were determined. It can be seen from Fig. 4 that $300 \mathrm{mg}$ of vanadium are quantitatively adsorbed by surface of synthesized 
composite in $\mathrm{pH}$ range from 1 to 8 . The high adsorption capacities of synthesized composite with respect of hexavalent molybdenum and chromium oxoions were observed at $\mathrm{pH} 2.5$ and in the neutral medium. However, the quantitative adsorption was not detected in all range of acidity of the medium. The maximum degree of sorption (from solution containing $1 \mathrm{mg}$ of molybdenum) by synthesized composite was about $92 \%$ in the acidic medium ( $\mathrm{pH} 2.5$ ) created with acetate ions.

As it can be seen from Fig. 4, 66 and $68 \%$ of molybdenum(VI) oxoanions were extracted from the slightly acidic medium at $\mathrm{pH} 5.0$ and from distilled water, respectively. In the strongly acidic medium $(\mathrm{pH} 1.0,0.1 \mathrm{M} \mathrm{HCl})$ the degree of adsorption of those oxoanions was $46 \%$ (Table 1 ). The lowest degree of adsorption $(40 \%)$ of molybdate-ions $\mathrm{MoO}_{4}{ }^{2-}$ has been observed in the slightly alkaline medium at $\mathrm{pH} 8.0$ generated by the ammonium acetate buffer. From solution containing $100 \mu \mathrm{g}$ of chromium, oxoions $\mathrm{Cr}(\mathrm{VI})$ were higher $(75-86 \%)$ concentrated by the synthesized composite in $\mathrm{pH}$ range from 2.5 to 5.0 in the presence of acetate ions and from the neutral medium. Similarly to molybdenum(VI), in the slightly alkaline medium at $\mathrm{pH} 8.0$ the adsorption of chromium(VI) is decreased (68\%). However, the lowest adsorption of chromate-ions (64\%) was detected in the strongly acidic medium $(\mathrm{pH} 1.0$, in the presence of chloride-ions).

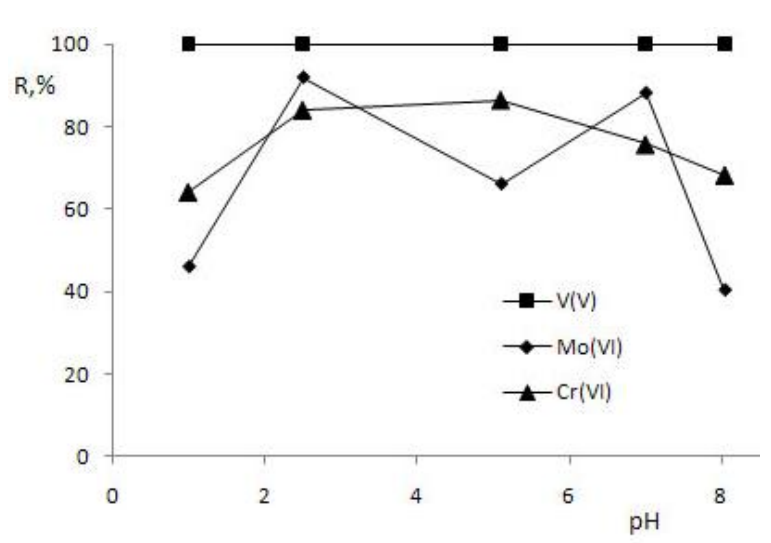

Fig. 4. The degree of adsorption of V(V), Mo(VI), and $\mathrm{Cr}(\mathrm{VI})$ oxoanions by composite chitosansaponite as a function of the medium acidity

Table 1. The degree of adsorption of $\mathrm{V}(\mathrm{V})$, $\mathrm{Mo}(\mathrm{VI})$, and $\mathrm{Cr}(\mathrm{VI})$ oxoanions as a function of the medium acidity (experimental conditions: weight of sorbent $-0.1 \mathrm{~g}$, volume of solution $-25 \mathrm{ml}$, content of chromium in the initial solution $-0.1 \mathrm{mg}$, vanadium $-0.3 \mathrm{mg}$, molybdenum $-1.0 \mathrm{mg}$ )

\begin{tabular}{cccccc}
\hline Oxoanions & \multicolumn{5}{c}{ Degree of adsorption, \% } \\
\cline { 2 - 6 } & $\begin{array}{c}\mathbf{p H ~ 1 . 0} \\
\mathbf{H C l}\end{array}$ & $\begin{array}{c}\mathbf{p H ~ 2 . 5} \\
\mathbf{C H}_{\mathbf{3}} \mathbf{C O O H}\end{array}$ & $\begin{array}{c}\mathbf{p H ~ 5 . 0} \\
\mathbf{C H}_{\mathbf{3}} \mathbf{C O O H}\end{array}$ & Distilled water & $\begin{array}{c}\text { pH 8.0 } \\
\text { ammonium } \\
\text { acetate buffer }\end{array}$ \\
\hline $\mathrm{V}(\mathrm{V})$ & 99.94 & 99.95 & 99.97 & 99.97 & 99.97 \\
\hline $\mathrm{Mo}(\mathrm{VI})$ & 46.12 & 91.87 & 66.13 & 88.10 & 40.48 \\
\hline $\mathrm{Cr}(\mathrm{VI})$ & 64.16 & 84.01 & 86.45 & 75.68 & 68.29 \\
\hline
\end{tabular}

Thus, the synthesized composite showed adsorption activity with respect to the investigated ions in the different $\mathrm{pH}$ ranges. The values of medium acidity, at which the maximum adsorption activities of chitosan-saponite composite for each of studied oxoanions were achieved, correspond to published data of complexation conditions of these ions with amino groups of chitosan in solutions [6-9].

Adsorption isotherms in the static mode for each ion were obtained for calculation of the values of the adsorption capacity of the composite. As it is shown in Fig. 5, the sorption activity of mineral with respect to quinquevalent vanadium oxoanions was increased in the presence of chitosan coating on the carrier surface. In the neutral medium one gram of synthesized composite extracts $0.51 \mathrm{mmol}$ of vanadate-ions $\mathrm{VO}_{3}^{-}$, and the isotherm of adsorption has the stair-step form (Fig. 5, curve 1). Under the same conditions, the initial saponite removes vanadium $(\mathrm{V})$ oxoanions with the maximum capacity $0.33 \mathrm{mmol} / \mathrm{g}$, but the isotherm of adsorption has concave form which confirms that vanadate-ions have low affinity to the saponite surface (Fig. 5, curve 2).

As shown in Fig. 6, from neutral solutions containing from $250 \mu \mathrm{g}$ to $10 \mathrm{mg}$ of metal the chitosan-saponite composite concentrates molybdate-ions $\mathrm{MoO}_{4}{ }^{2}$ with maximum adsorption capacity $0.4 \mathrm{mmol} / \mathrm{g}$. In the acidic medium at $\mathrm{pH} 2.5$ the composite removes mixture of $\mathrm{MoO}_{4}{ }^{2-}$, $\left[\mathrm{Mo}_{6} \mathrm{O}_{21}\right]^{6-},\left[\mathrm{Mo}_{7} \mathrm{O}_{24}\right]^{6-}$ oxoanions with maximum adsorption capacity $0.73 \mathrm{mmol} / \mathrm{g}$. In the similar conditions, initial saponite adsorbs $\mathrm{Mo}(\mathrm{VI})$ 
oxoanions with maximum capacity $0.22 \mathrm{mmol} / \mathrm{g}$ but initially (content of metal from 0.25 to $2.50 \mathrm{mg}$ ) the isotherm of adsorption has concaved form which confirms that molybdate-ions have lower affinity to the saponite surface in comparison with that to the surface of organo-mineral composite. The character of isotherms confirms the monolayered distribution of mixture of polymolybdate-ions on the surface as a result of complexation or formation of ionic associates with protonated amino groups of immobilized polymer at $\mathrm{pH} 2.5$ (Fig. 6, curve 1), as well as in the neutral medium (Fig. 6, curve 2).

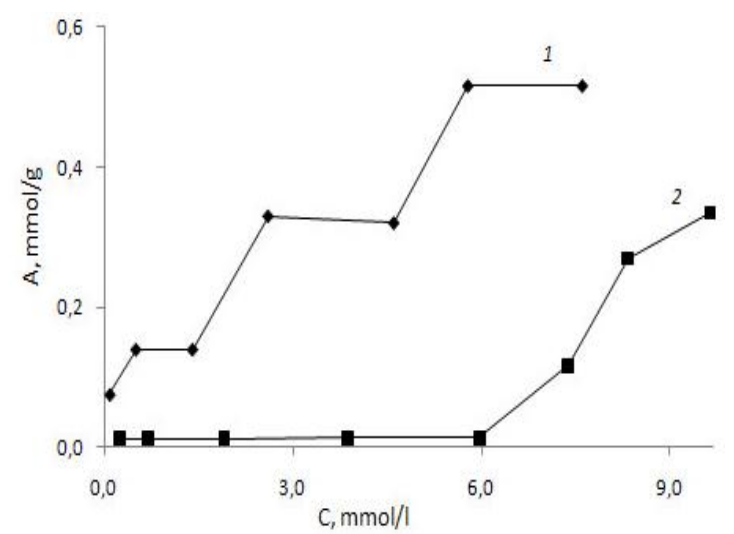

Fig. 5. Adsorption isotherms of $\mathrm{V}(\mathrm{V})$ oxoanions by chitosan-saponite composite (1) and initial saponite (2) in the neutral medium

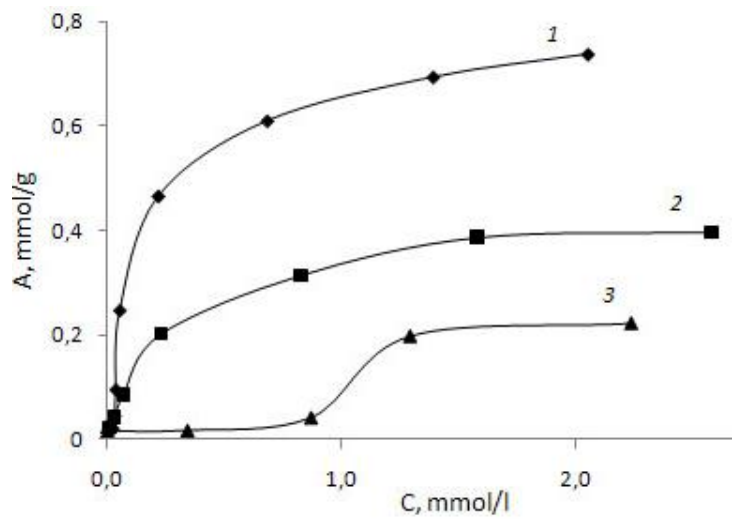

Fig. 6. Adsorption isotherms of $\mathrm{Mo}(\mathrm{VI})$ oxoanions by chitosan-saponite composite at $\mathrm{pH} 2.5$ (1) and from disstilled water (2), and by initial saponite at $\mathrm{pH} 2.5$ (3)

Initial saponite does not adsorb dichromateions, whilst the composite chitosan-saponite has shown high adsorption capacity with respect to these anions (Fig. 7). Adsorption capacity of synthesized composite with respect of $\mathrm{Cr}(\mathrm{VI})$ oxoanions is $0.59 \mathrm{mmol} / \mathrm{g}$.

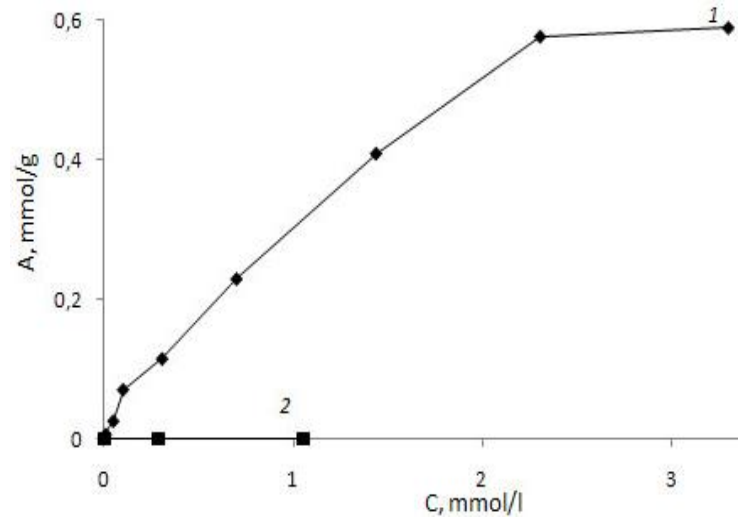

Fig. 7. Adsorption isotherms of $\mathrm{Cr}(\mathrm{VI})$ oxoanions by chitosan-saponite composite (l) and initial saponite at $\mathrm{pH} 5.0$ (2)

Obtained values of the adsorption capacities of the composite chitosan-saponite and initial saponite, as well as maximum degrees of adsorption of $\mathrm{V}(\mathrm{V}), \mathrm{Mo}(\mathrm{VI}), \mathrm{Cr}(\mathrm{VI})$ oxoanions from solutions with different concentrations of metals are shown in Table 2.

Taking into account that there are $9.1 \%$ of chitosan and $90.9 \%$ of mineral in the composite, we have estimated the contribution of organic and inorganic part to the maximum adsorption capacity $\left(A_{\max }\right)$ with respect to each of studied ions (Fig. 8). $A_{\max }$ of crosslinked chitosan (5\% of aminogroups were crosslinked by glutaraldehyde) with respect of $\mathrm{V}(\mathrm{V})$ oxoanions with initial mass of vanadium $7.5 \mathrm{mg}$ in the neutral medium is $0.09 \mathrm{mmol} / \mathrm{g}$, saponite $-0.11 \mathrm{mmol} / \mathrm{g}$. Under the same conditions, $A_{\max }$ for composite chitosan-saponite is $0.52 \mathrm{mmol} / \mathrm{g}$, which 2.5 times higher than sum of maximum adsorption capacities of the starting components.

In the acidic medium generated by acetic-ions ( $\mathrm{pH} 2.5)$, crosslinked chitosan adsorbs $\mathrm{Mo}(\mathrm{VI})$ oxoanions with $A_{\max } 0.07 \mathrm{mmol} / \mathrm{g}$, saponite $0.38 \mathrm{mmol} / \mathrm{g}$, but in the same conditions the synthesized composite extracts almost 2.5 times more than initial compounds ( $A_{\max }$ runs up to $0.63 \mathrm{mmol} / \mathrm{g}$ ). It is interesting that the synthesized composite adsorbs chromium(VI) at pH 5.0 with adsorption capacity $0.15 \mathrm{mmol} / \mathrm{g}$ which 5 times higher than capacity of partly crosslinked chitosan under the same experimental conditions: one gram of crosslinked chitosan concentrates $0.02-0.03 \mathrm{mmol} / \mathrm{g}$ $\mathrm{Cr}(\mathrm{VI})$ oxoanions from the acidic $(\mathrm{pH} 2.5)$ and neutral media. Saponite does not show adsorption activity with respect to dichromate-ions $\mathrm{Cr}_{2} \mathrm{O}_{7}{ }^{2-}$ at pH 5.0 (acetate buffer). 
Table 2. Adsorption capacity of chitosan-saponite composite and initial saponite and maximum degree of adsorption of $\mathrm{V}(\mathrm{V}), \mathrm{Mo}(\mathrm{VI}), \mathrm{Cr}(\mathrm{VI})$ oxoanions from solutions with various metal concentrations

\begin{tabular}{ccccc}
\hline Oxoanion & Mo(VI) & Cr(VI) & V(V) & Mo(VI) \\
\hline pH & $\mathbf{2 . 5}$ & $\mathbf{5 . 0}$ & \multicolumn{2}{c}{ Distilled water } \\
\hline $\begin{array}{c}\text { adsorption capacity, } \\
\text { mmol/g }\end{array}$ & 0.73 & 0.59 & 0.52 & 0.40 \\
$\begin{array}{c}\text { Composite chitosan-saponite } \\
\text { adsorption, } \%\end{array}$ & $\begin{array}{c}\left(m_{0}=2.5 \mathrm{mg}\right)^{*} \\
\text { ads degree of }\end{array}$ & $\begin{array}{c}\left(m_{0}=100 \mu \mathrm{gg}\right) \\
\text { Saponite }\end{array}$ & $\begin{array}{c}\left(m_{0}=1 \mathrm{mg}\right) \\
\left(m_{0}=250 \mu \mathrm{g}\right)\end{array}$ \\
$\begin{array}{c}\text { adsorption capacity, } \\
\text { mmol/g }\end{array}$ & 0.22 & 0 & 0.33 & - \\
$\begin{array}{c}\text { maximum degree of } \\
\text { adsorption, } \%\end{array}$ & 100 & - & 36 & - \\
\hline
\end{tabular}

$* m_{\mathrm{o}}$ - initial content of metal in the solution

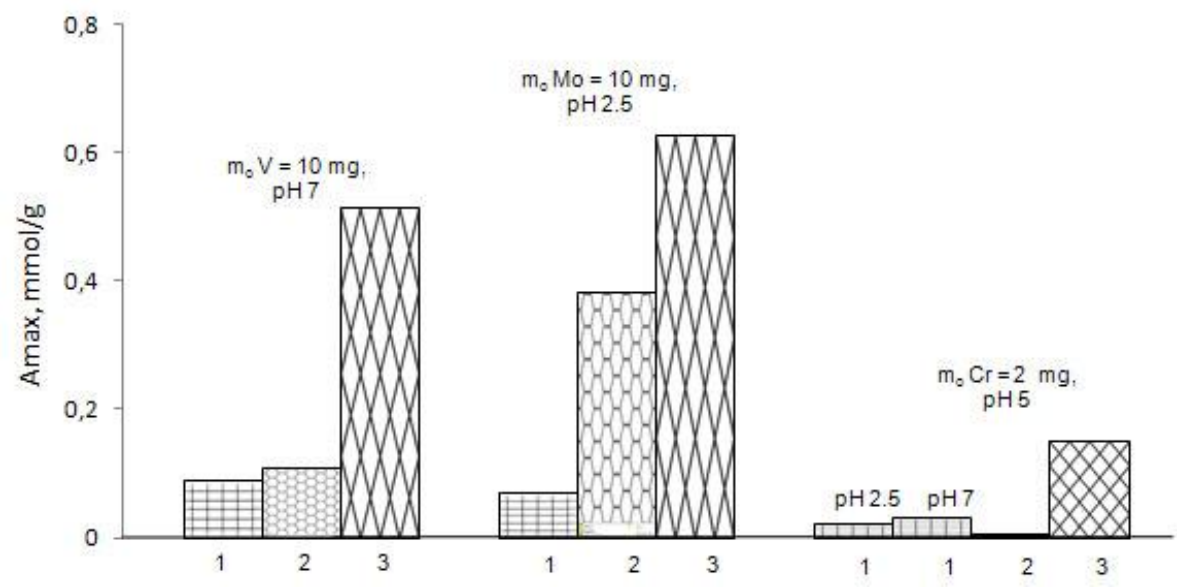

Fig. 8. Comparion (according to mass ratios in the composite) of adsorption capacity of chitosan (1), saponite (2), and composite chitosan-saponite (3) with respect to $\mathrm{V}(\mathrm{V}), \mathrm{Mo}(\mathrm{VI})$, and $\mathrm{Cr}(\mathrm{VI})$ oxoanions

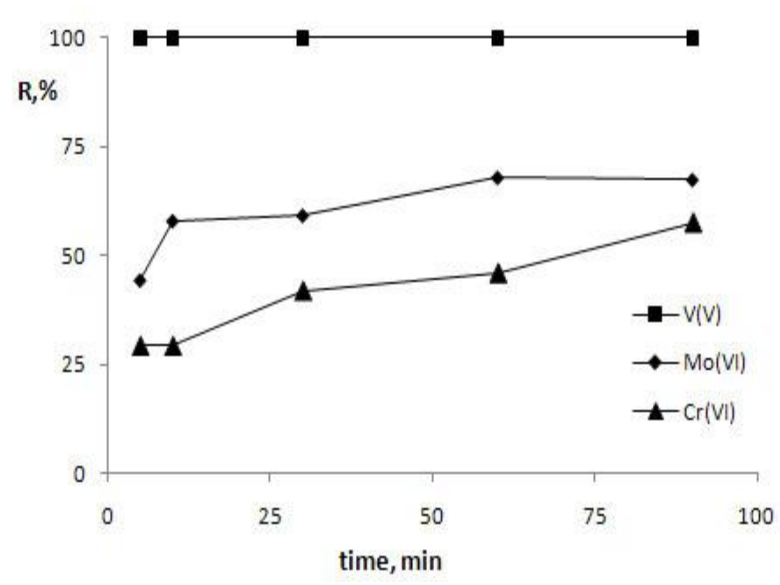

Fig. 9. Dependence of degree of adsorption $(R, \%)$ on time of contact with solutions containing $300 \mu \mathrm{g}$ of vanadium in distilled water, $1000 \mu \mathrm{g}$ of molybdenum at $\mathrm{pH} 2.5$, and $100 \mu \mathrm{g}$ of chromium at $\mathrm{pH} 5.0$
According to obtained results for all studied ions (Fig. 9), the degree of adsorption consistently increases during several hours, which is typical for polymeric adsorbents where the sorption characteristics are defined by interaction between ions and functional groups of supported chitosan.

\section{CONCLUSION}

The composite chitosan-saponite was synthesized by crosslinking of adsorbed biopolymer with glutaraldehyde. IR spectroscopy confirmed the fact of immobilization of chitosan in the surface layer of silica. According to the thermogravimetric analysis, the obtained composite contains $9.1 \%$ of chitosan.

Saponite with immobilized chitosan on its surface showed better adsorption properties towards microquantities of vanadium, molybdenum, chromium in aqueous solutions in comparison with unmodified mineral. Adsorption 
capacity of the synthesized composite with respect to: vanadium $(\mathrm{V})-0.52 \mathrm{mmol} / \mathrm{g}$ in the neutral medium; molybdenium(VI) - 0.73 and $0.40 \mathrm{mmol} / \mathrm{g}$ at $\mathrm{pH} 2.5$ and in distilled water, respectively; chromium(VI) $-0.59 \mathrm{mmol} / \mathrm{g}$ at $\mathrm{pH}$ 5.0. Unmodified mineral removes vanadium(V) oxoanions with maximum adsorption capacity $0.33 \mathrm{mmol} / \mathrm{g}$, molybdenum(VI) oxoanions $0.22 \mathrm{mmol} / \mathrm{g}$ at $\mathrm{pH} 2.5$ and does not show adsorption activity with respect to chromium(VI) at $\mathrm{pH}$ 5.0. It was shown that the synthesized composite extracted studied metals for the day.

\section{ACKNOWLEDGEMENTS}

The research leading to these results has received funding from the Visegrad 4 Eastern Partnership Program of the International Visegrad Fund under contaract for financing Visegrad/V4EaP Scholarship No 51400001 and from the People Programme (Marie Curie Actions) of the European Union's Seventh Framework Programme FP7/2007-2013/ under REA grant agreement $\mathrm{n}^{\circ}$ PIRSES-GA-2013-612484. The authors thanks Dr. M.V. Borysenko for the help in thermogravimetric measurements.

\title{
Іммобілізований на поверхні подільського сапоніту хітозан в процесах екстракції V(V), Mo(VI) та $\mathrm{Cr}(\mathrm{VI})$ оксоаніонів
}

\author{
Т.М. Будняк, В.А. Тьортих, Е.С. Яновська
}

Інститут хімії поверхні ім. О.О. Чуйка Національної академії наук Украӥни, вул. Генерала Наумова, 17, Київ, 03164, Україна, tetyanabudnyak@yahoo.com Київський національний університет імені Тараса Шевченка, хімічний факультет вул. Володимирська, 64, Київ, 01033, Україна

\begin{abstract}
Композит хітозан-сапоніт одержсано зиивкою глутаровим альдегідом адсорбованого на поверхні Подільського сапоніту біополімеру. Будову поверхні композит досліджено методом ІЧ-спектро-скопії, a кількість іммобілізованого хітозану визначено за допомогою термогравіметричного аналізу. Проведено оцінку адсорбиійних характеристик синтезованого композит щэодо мікрокількостей $V(V)$, Mo(VI) і Cr(VI) оксоаніонів у водних розчинах у порівнянні з властивостями вихідних природного мінералу $i$ полімеру. Визначено сорбиійну ємність та кінетичні характеристики одержсаного композитного адсорбенту.
\end{abstract}

Ключові слова: адсорбиія, хітозан, сапоніт, глина, ванадій, молібден, хром

\section{Иммобилизованный на поверхности подольского сапонита хитозан в процессах экстракции V(V), Mo(VI) и Cr(VI) оксоанионов}

\section{Т.Н. Будняк, В.А Тертых, Э.С. Яновская}

Институт химии поверхности им. А.А. Чуйко Национальной академии наук Украины ул. Генерала Наумова, 17, Киев, 03164, Украина, tetyanabudnyak@yahoo.com

Киевский национальный университет имени Тараса Шевченко, химический факультет ул. Владимирская, 64; Киев, 01033, Украина

Композит хитозан-сапонит получен сшивкой адсорбированого на поверхности Подольского сапонита биополимера глутаровым альдегидом. Структура поверхности композита изучена методом ИК-спектроскопии, а концентрачия иммобилизованого хитозана установлена из данных термогравиметрического анализа. Проведена оиенка адсорбиионных характеристик синтезированого 
композита по отномению к микроколличествам оксоанионов $V(V), \quad M o(V I)$ и $C r(V I)$ в водных растворах в сравнении со свойствами исходных природного минерала и полимера. Установлена сорбиионная емкость и кинетические характеристики полученного композитного адсорбента.

Ключевье слова: адсорбиия, хитозан, сапонит, глина, ванадий, молибден, хром

\section{REFERENCES}

1. Chekman I.S., Ovrutskiy V.I., Shumeyko V.M. et al. Clay as a drug, Pharm. J., 1 (1991) 22 (in Ukrainian).

2. Gyrin V.M., Boiko I.I., Rudichenko V.F. Application of natural mineral saponite for water disinfection, Likarska sprava, 5-6 (1995) 177 (in Ukrainian).

3. Chelyshev N.F., Volodin V.F., Kryukov V.L. Ion-exchanging Properties of Natural Zeolites, Moscow, Science, 1988, 129 p. (in Russian).

4. Tsitsishvili G.V., Andronikashvili T.G., Kirov G.N., Filizova L.D. Natural Zeolites, Moscow, Chemistry, 1985, 224 p. (in Russian).

5. Tarasevich Yu.I. Natural Sorbents for Water Purification, Kyiv, Naukova dumka, 1981, 207 p. (in Ukrainian).

6. Budnyak T.M., Tertykh V.A., Yanovska E.S. Chitosan and its derivatives as sorbents for effective removal of metal ions, Surface, 5(20) (2013) 118 (in Ukrainian).

7. Varma A.J., Deshpande S.V., Kennedy J.F. Metal complexation by chitosan and its derivatives: a review, Carbohydr. Polym., 55 (2004) 77.

8. Grini G. Recent development in polysaccharide-based materials used as adsorbents in wastewater treatment, Prog. Polym. Sci., 30 (2005) 38 .

9. Singhon R., Husson J., Knorr M., Euvrard M. Preparation of silica-supported biosorbents for copper(II) removal, J. Disper. Sci. Technol., 32 (2011) 1735.

10. Repo E., Warchot J.K., Bhatnagar A., Sillanpää $M$. Heavy metals adsorption by novel EDTA-modified chitosan-silica hybrid materials, J. Colloid Interf. Sci., 358 (2011) 261.

11. Gandhi M.R., Meenakshi S. Preparation and characterization of silica gel/chitosan composite for the removal of $\mathrm{Cu}$ (II) and $\mathrm{Pb}(\mathrm{II})$, Int. J. Biol. Macromol., 50 (2012) 650.

12. He J.-C., Zhou F.-Q., Mao Y.-F. et al. Preconcentration of trace cadmium(II) and copper(II) in environmental water using a column packed with modified silica gelchitosan prior to flame atomic absorption spectrometry determination, Analytical Letters, 46 (2013) 1430.

13. Copello G.J., Varela F., Vivot R.M., Díaz L.E. Immobilized chitosan as biosorbent for the removal of $\mathrm{Cd}(\mathrm{II}), \mathrm{Cr}(\mathrm{III})$ and $\mathrm{Cr}(\mathrm{VI})$ from aqueous solutions, Bioresource Technol., 99 (2008) 6538.

14. Wan Ngah W.S., Teong L.C., Hanafiah M.A.K.M. Adsorption of dyes and heavy metal ions by chitosan composites: A review, Carbohydr. Polym., 83 (2011) 1446.

15. Kalyani S., Priya J.A., Rao P.S., Krishnaiah A. Removal of copper and nickel from aqueous solutions using chitosan coated on perlite as biosorbent, Separ. Sci. Technol., 40 (2005) 1483.

16. Kalyani S., Krishnaiah A., Boddu V.M. Adsorption of divalent cobalt from aqueous solution onto chitosan-coated perlite beads as biosorbent, Separ. Sci. Technol., 42 (2007) 2767.

17. Dragan E.S., Dinu M.V. Removal of copper ions from aqueous solution by adsorption on ionic hybrids based on chitosan and clinoptilolite, Ion Exchange Letters, 2 (2009) 15.

18. Zou X., Pan J., Ou H. et al. Adsorptive removal of $\mathrm{Cr}(\mathrm{III})$ and $\mathrm{Fe}(\mathrm{III})$ from aqueous solution by chitosan/attapulgite composites: Equilibrium, thermodynamics and kinetics, Chem. Eng. J., 167 (2011) 112.

19. Gupta N., Kushwaha A.K., Chattopadhyaya M.C. Adsorptive removal of $\mathrm{Pb}^{2+}, \mathrm{Co}^{2+}$ and $\mathrm{Ni}^{2+}$ by hydroxyapatite/chitosan composite from aqueous solution, J. Taiwan Inst. Chem. E, 43 (2012) 125.

20. Tirtom V.N., Dinçer A., Becerik S. et al. Comparative adsorption of $\mathrm{Ni}$ (II) and $\mathrm{Cd}($ II) ions on epichlorohydrin crosslinked chitosanclay composite beads in aqueous solution, Chem. Eng. J., 197 (2012) 379.

21. Tirtom V.N., Dinçer A., Becerik S. et al. Removal of lead(II) ions from aqueous solution by using crosslinked chitosan-clay beads, Desalination and Water Treatment, 39 (2012) 76.

22. Korostyliov P.P. Solution Preparation for Chemical-Analytical Application, Moscow, Science, 1964, 399 p. (in Russian). 
23. Marchenko Z., Balcerzak M. Spectrofotometry Metods in Inorganic Analisys, Warsaw, Naukove, Naukowe PWN, 1998 (in Polish).

24. Muzgin V.N., Halezina V.L., Zolotavin V.L., Bezrukov I.Ya. Analytical Chemistry of Vanadium, Moscow, Science, 1981, 215 p. (in Russian).

25. Wan Ngah W.S., Teong L.C., Wong C.S., Hanafiah M.A.K.M. Preparation and characterization of chitosan-zeolite composites, J. Appl. Polym. Sci., 125 (2012) 2417.

26. Perminov P.A. Patterns of interaction of chitosan with glutaraldehyde and their use in the preparation of enzyme-polymer materials: Ph.D (speciality 02.00.06) Thesis Abstract, A.N. Kosygin MSU, Moscow, 2010, 16 p. (in Russian).

27. Guibal E., Milot C., Tobin J. Metal-anion sorption by chitosan beads: equilibrium and kinetic studies, Ind. Eng. Chem. Res., 37 (1998) 1454.
28. Futalan C. M., Kan C. C., Dalida M. L. et al. Fixed-bed column studies on the removal of copper using chitosan immobilized on bentonite, Carbohydr. Polym., 83 (2011) 697.

29. Jaworska M., Sakurai K., Gaudon P., Guibal E. Influence of chitosan characteristics on polymer properties. I: Crystallographic properties, Polym. Int., 52 (2003) 198.

30. Yang X., Tu Y., Shang S., Tao X. Welldispersed chitosan/graphene oxide nanocomposites, App. Mater. Interfaces, 2 (2010) 1707.

31. Budnyak T.M., Yanovska E.S., Tertykh V.A., Voznyk V.I. Adsorption properties of composite Sokirnitsky clinoptilolitepolyaniline towards anions of elements $\mathrm{V}$ and VI groups of D.I. Mendeleev Periodic System, Reports of the National Academy of Sciences of Ukraine, 3 (2011) 141 (in Ukrainian).

Received 01.07.2014, accepted 17.09.2014 